\title{
도덕과 교육에서의 법교육 내용 분석과 개선 연구
}

\author{
윤 현 진 \\ (한국교육과정평가원)
}

\section{I. 도덕과 교육어서 법교육의 중요성}

사람들이 모여 사는 사회에는 행위 규칙이 존재하 기 마련이며, 이를 우리는 규범이라 한다. 그 형태는 관습, 예절, 도덕, 법으로 나타나며, 이러한 규범이 지 켜지지 않을 경우 사회 구성원 간에 갈등이 일어난다. 관습이 지켜지지 않으면 서로 어색해지고, 예절이 지 켜지지 않으면 기분이 언짢아지며, 도덕이 지켜지지 않으면 사람 간의 관계가 격이 낮아지고 추해 보이며, 법이 지켜지지 않으면 심신의 위험과 재산상의 손해 에 관련된 분쟁이 일어난다. 학교에서는 사람들 속에 서 발생하는 이런 일들을 가르쳐야 한다. 그런데 현실 에서 이들 사회 규범이 엄격하게 구분되기는 어렵다. 전통 사회에서는 관습과 예절, 도덕이 거의 비슷한 개 념으로 인식되었으며 현대 사회로올수록 도덕의 항목 이 법률로 규정되는 경우가 많다. 그 예로 법에서 추 구하는 정의, 공정성, 형평성이 도덕에서도 중요한 내 용 또는 항목으로 다루어지고 있다.

윤리학자 워녹(G. J. Warnock)은 인간의 본성에 대 한 흄(D. Hume)의 분석과 비슷하게 인간은 본래 남 보다는 자기 자신의 이익을 우선적으로 추구하고, 다 른 부족이나 국가의 이익보다는 자신의 부족이나 국 가의 이익을 더 우선적으로 추구하며, 또 대부분의 경 우 자신의 이익을 추구하기 위해 고의적으로 타인에 게 해를 끼친다고 보았다. 그리고 이러한 경향은 인간 의 동정심이 제한되어 있기 때문이며 또 이러한 제한 된 동정심으로 인해 발생하는 문제가 도덕적으로 발 생하는 문제의 핵심이 된다고 보았다. 따라서 도덕의 근본적인 목적 또는 존재 이유는 다른 무엇보다도 인
간이 갖고 있는 제한된 동정심을 교정하여 인간의 곤 경을 없애거나 줄이는 데 있다는 결론에 도달했다(G. J. Warnock, 1971, p.16.) 그에 의하면, 전통적으로 도 덕에서 중요하게 다루어왔던 근면, 절제, 근신, 용기와 같은 덕목들은 남들을 위해 사용될 수 있는 것이긴 하지만 때로는 자신만을 위해 사용될 수 있기 때문에 정의, 공평성, 형평성 등이 도덕의 내용으로 더욱 중 요하다고 주장한다. 이처럼 법과 도덕은 엄격히 구분 되기 어려우며 특히 복잡하고 다원화된 현대 사회에 서 이러한 경향은 더욱 분명해진다.

교육이 지향해야 할 것은 단순한 지식 차원의 것이 아니다. 교육은 세계를 보는 틀을 형성하는 데 관심을 가져야 한다. 도덕이나 법과 같은 행위 규칙의 개념화 양식은 이러한 틀을 형성하는 하나의 예로서, 도덕이 나 법을 어떻게 개념화했는가에 따라서 세계를 바라 보는 시각이 달라진다. 예컨대 어떤 아동은 도덕이나 법을 절대자 혹은 부모로부터 벌을 받지 않기 위해서 지킨다고 생각할 수도 있고, 어떤 아동은 도덕과 법을 지키면 누구에게나 좋은 일이 생긴다고 개념화 할 수 도 있다. 이 경우, 한 아이는 도덕과 법을 벌과 관련 지어 생각하고, 다른 아이는 법을 공존의 원리로 이해 하고 있는 것이다. 따라서 도덕 교육과 법교육은 깊이 연관되어 있으며 도덕과 법에 대한 학생들의 올바른 시각을 갖게 하기 위한 법교육이 도덕 교육에서 매우 의미있다. 사회과 교육에서의 법교육이 법의 연원, 법 의 현실 적용, 법률 관계, 헌법 민법 등 법의 종류와 내용에 비중을 둔다면 도덕과 교육에서는 법과 도덕 의 공통점과 차이점, 법의 근본 정신, 인간 존중의 하 나로서의 준법 등을 다루는 것이다. 


\section{II. 선행 연구 분석}

본 연구와 관련된 선행 연구들로는 법교육의 이론 적 근거가 되는 법태도1)에 관한 연구와, 법교육의 실 태 및 내용과 방법에 관한 연구들이 있다.

법태도에 관한 연구는 크게 인지발달론적 연구와 경험 분석적 연구로 나누어 볼 수 있다. 법태도에 관한 인지발달론적 연구는 삐아제(Piaget), 콜버그 (Kohlberg), 탭과 레빈(Tapp \& Levine) 등에 의해 이루어졌는데, 법의식 발달과 인지 발달은 깊은 관계 에 있다는 전제하에 주로 법의식 발달의 문화적 보편 성 여부와 발달 단계의 순차성을 검증하는 데 초점을 두고 있다. 법태도에 관한 경험 분석적 연구는 사회 심리학적 입장에서의 연구로서, 법태도의 하위 범주를 설정하고 학생들의 법태도를 조사하였다. 이러한 연구 로는 법태도를 경험적 분석이 가능할 수 있도록 과학 적 개념으로 체계화시킨 흘레저와 스미스(Fraser \& Smith)의 연구가 있으며, 우리 나라에서는 임희섭과 이수성의 연구에서 그 대표적 예를 찾을 수 있다.

법태도에 관한 연구를 바탕으로 법교육의 실태를 파악하고 그 방법을 개선시키고자 한 연구에는 조영 달과 박성혁의 "한국 학생의 법태도 발달과 법교육 개선에 관한 연구"와 문용린의 “청소년의 도덕성, 법 의식 발달, 비행 경향성 및 법교육 실태에 관한 연구" 가 있다. 이 연구들은 본 연구와 밀접한 관련을 갖고 있으므로, 그 연구 내용을 검토·분석하고 본 연구의 방향을 제시하기로 한다. 조영달과 박성혁의 연구는 Fraser \& Smith의 법태도 측정과 임희섭, 이수성 등 의 법의식 조사 연구를 참고하여, 우리 나라 초- 중. 고 학생들의 법태도를 조사하고 이를 기초로 학교 법 교육의 개선 방향을 제시하고 있다. 이 연구에 의하 면, 우리 나라 학생들의 법인식관에는 법의 본질을 초 월적 - 도덕적 - 징벌적 · 형벌적 성격에서 찾는 전근대 적 요소와 사회적·게약적·민법적 성격에서 찾는 근 대적 요소가 혼재되어 있으며, 이러한 법인식관은 학 년 수준이 올라가도 변화가 없이 정체되어 있다. 그리 고 법에 대한 낮은 흥미감과 신뢰감으로 인하여 학년 수준이 올라갈수록 법에 대한 무력감과 기피 성향이

1) 법태도는 법의식과 크게 구분되지 않고 사용된다.
점점 커지고 있다. 그러나 현행의 학교 법교육은 순수 법학 지식의 내용을 학생들에게 단순히 전달하거나 입학 시험 위주의 교과 중심적인 방향에 치중된 나머 지 학생들의 법태도 발달에는 크게 기여하지 못하고 있다. 따라서 학교 법교육은 학생들의 법 흥미감 제 고, 법교육과 법현실의 연계, 교수-학습 방법의 다양 화, 법교육에 대한 교사의 적극적인 인식의 강화가 필 요하다는 것이다(조영달, 박성혁, 1992, 24-27쪽).

문용린의 연구는 동일한 인지 구조가 상이한 상황 에 적용되어 나타나는 것이 바로 도덕성, 법의식이라 는 관점에서, 우리 나라 청소년(중·고등학생)의 도덕 성과 법의식 및 비행 경향성의 발달적 특성을 조사하 였다. 조사 결과 우리 나라 청소년의 도덕성은 다른 사회와 비교해 볼 때 사회 계약적 관점 혹은 보편적 원리 원칙의 관점에 근거한 5,6 단계의 비율이 높은 편이나, 법의식 수준은 자기 충족의 수단으로 보거나 소집단의 이해 관계 속에서 파악하는 2,3 단계 수준에 있는 것으로 나타났다. 또한 이 연구는 도덕성과 법의 식은 비행 경향성과 부적 상관을 이룬다고 밝혔으며 청소년의 비행을 도덕적 · 법적 차원에서 고려해야 한 다는 점을 주장하고 있다. 결론적으로 현행의 법교육 은 청소년의 법의식 발달을 제대로 수행하기 어려운 실태로 파악하였다. 현재 이루어지고 있는 법교육은 주로 법일반에 관한 내용이나 헌법의 해설에 치우치 고 있다는 점, 교과서 내용이 현실과 연계가 없다는 점, 수업 방식이 강의식 입시 준비 위주라는 점 등의 문제점을 가지고 있기 때문이라는 것이다. 따라서 이 러한 문제점을 극복할 수 있는 법교육의 개선 방안으 로 다음 네 가지를 제시한다. 사법 교육을 강화하는 교육과정상의 개선, 현실과 연계되는 교과서 내용 구 성상의 개선, 교수- 학습 방법상의 개선, 흥미를 유도 한 교과서 내용상의 개선이 그것이다(문용린, 1994, 99- 101쪽).

이와 같은 법교육에 관한 선행 연구는 법교육의 방 향 설정에 많은 도움이 된다. 더불어 살아가는 현대 민주 사회의 시민으로서 갖추어야 할 필수적인 요소 중의 하나인 법의식 발달은 법교육이 담당해야 할 몫 이라는 제안과 현행 법교육의 문제점과 그를 극복할 수 있는 방안의 제시가 그것이다. 그러나 이들의 연구 에서 몇 가지 아쉬운 점이 있다. 첫째, 법교육과 직접 
적으로 관련된 교과는 사회과라고 규정한 점이다. 그 러한 근거의 하나로 미국의 사회과 교육의 하위 목표 영역을 제시하고 있는데, 미국의 사회과 교육은 우리 의 사회과와 도덕과가 통합된 교과임을 감안해야 할 것이다. 도덕과가 별도의 교과로 설정되어 있는 우리 나라에서는 도덕과에서도 법교육을 담당해야 한다. 법 교육이 학생들에게 법률 지식을 이해시키는 데 그칠 것이 아니라 법질서를 존중하고 신뢰하도록 하기 위 해서는 내면화와 실천 과정이 중요하기 때문이다. 둘 째, 현행 법교육의 문제점을 극복하기 위해 제시된 방 향은 바람직한데 그 방안이 구체적이지 못하여, 교과 서 내용 구성이나 수업 방법에서 실질적인 도움을 받 기 어렵다. 셋째, 법에 대한 이해 혹은 인식이 법실증 주의에 치우쳐 있다. 우리 학생들의 법인식관에 문제 가 있는 것은 사실이다. 그러나 법을 도덕적 - 징벌적 - 형벌적 도구로 인식하는 한 법에 대한 자신감이나 긍정적인 태도의 형성이 어려울 수 밖에 없다는 가정 은 근거가 약하다. 서구의 근대적 법인식관에도 법을 도덕적으로 보는 자연법적 사고가 존재하며 중요하게 여겨진다. 또한 우리 나라에서 법에 대한 흥미와 신뢰 감이 약하게 된 데는, 법을 인간에 만들어진 일종의 계약으로서 강자의 필요에 의해 개정 가능한 것으로 여기는 실정법적 사고가 팽배했기 때문이라고 볼 수 도 있다.

법교육은 법에 대한 지식을 알고 이를 일상 생활에 서 효율적으로 사용하는 것만으로 충분하지 않다. 법 을 신뢰하고 준수하려는 태도의 내면화와 실천이 중 요하며, 이는 도덕과 교육을 통해 가능하다. 따라서 본 연구에서는 도덕과 교육에서 법교육 실태를 분석 하고 그 개선 방안을 모색하였다.

\section{III. 도덕과 교육에서의 법교육 시례 분석}

\section{1. 도덕과 교육과정의 법교육 내용}

제 6차 도덕과 교육과정에 설정된 법교육 관련 내 용은 주로 사회 생활 영역이다. 지도 요소로는 공공 질서, 공익, 공정, 민주적 절차 등이며, 초. 중학교의 구체적인 관련 규범은 다음과 같다. 고등학교 교육과 정에서는 법교육 관련 규범이 없다.
초등학교 교육과정의 법교육 내용 체계

\begin{tabular}{|c|c|c|c|c|c|}
\hline $\begin{array}{l}\text { 생 활 } \\
\text { 영 역 }\end{array}$ & $\begin{array}{l}\text { 지 도 } \\
\text { 요 소 }\end{array}$ & 3학년 & 4학년 & 5 학년 & 6학년 \\
\hline \multirow{4}{*}{$\begin{array}{l}\text { 사 회 } \\
\text { 생 활 }\end{array}$} & $\begin{array}{ll}\text { 공 공 } \\
\text { 질 서 }\end{array}$ & $\begin{array}{c}\text { 공중 } \\
\text { 도덕 } \\
\text { 지키기 }\end{array}$ & $\begin{array}{c}\text { 다른 } \\
\text { 사람의 } \\
\text { 이익 존중 }\end{array}$ & $\begin{array}{c}\text { 법을 } \\
\text { 지키는 } \\
\text { 태도 }\end{array}$ & $\begin{array}{c}\text { 법의 정신 } \\
\text { 이해 }\end{array}$ \\
\hline & 공 익 & & & & $\begin{array}{c}\text { 개인의 } \\
\text { 이익과 } \\
\text { 공동 } \\
\text { 이익 간의 } \\
\text { 조화 }\end{array}$ \\
\hline & 공 정 & $\begin{array}{l}\text { 사람 차별 } \\
\text { 하지 않기 }\end{array}$ & $\begin{array}{c}\text { 정의감과 } \\
\text { 용기 }\end{array}$ & $\begin{array}{c}\text { 다른 } \\
\text { 사람의 } \\
\text { 권리 존중 }\end{array}$ & $\begin{array}{c}\text { 정의로운 } \\
\text { 사회를 } \\
\text { 이룩하려는 } \\
\quad \text { 자세 }\end{array}$ \\
\hline & $\begin{array}{l}\text { 민주적 } \\
\text { 절 차 }\end{array}$ & & & $\begin{array}{l}\text { 합리적인 } \\
\text { 문제 해결 }\end{array}$ & \\
\hline
\end{tabular}

중학교 교육과정의 법교육 내용 체계

\begin{tabular}{|c|c|c|c|}
\hline 영 역 & 1학년 & 2학년 & 3학년 \\
\hline $\begin{array}{l}\text { 개 인 } \\
\text { 생 활 }\end{array}$ & $\begin{array}{l}\text { 인간의 삶과 } \\
\text { 도덕성 }\end{array}$ & & \\
\hline $\begin{array}{l}\text { 사 회 } \\
\text { 생 활 }\end{array}$ & $\begin{array}{l}\text { 현대 사회의 } \\
\text { 공중 도덕 } \\
\text { 현대 사회의 } \\
\text { 시민윤리 }\end{array}$ & $\begin{array}{l}\text { 사회적 도덕 } \\
\text { 문제의 해결 }\end{array}$ & $\begin{array}{l}\text { 민주 사회와 } \\
\text { 인간 존중 } \\
\text { 민주적 태도 } \\
\text { 와 생활 양식 }\end{array}$ \\
\hline
\end{tabular}

\section{2. 초등학교 도덕 교과서의 법교육 내용}

초등학교 도덕 교과서에 제시된 법교육 관련 내용 은 직접적인 규범으로 법을 지키는 태도와 법의 정신 이해가 있으며, 간접적인 규범으로 다른 사람의 이익 존중, 다른 사람의 권리 존중, 사람 차별하지 않기 등 이 포함되어 있다. 그 구체적인 내용을 학년별로 살펴 보면 다음과 같다.

$$
\text { 가. } 3 \text { 학년 }
$$

3 학년 교과서에서는 2 개 제재에 법교육 내용이 제 시되어 있으며 지도 요소는 공중 도덕 지키기와 사람 차별하지 않기이다. 먼저 공중 도덕 지키기는 1 학기에 ‘우리가 지켜야 할 일'이라는 제재명으로 제시되었는데 준법 정신의 기초 단계이다. 그 내용은 다음과 같다. 
길거리에 휴지가 여기 저기 흩어져 있고, 사람 들이 아무 쪽으로나 오고 간다면 어떻게 되겠습 니까?

여러 사람들이 함께 살아가면서 서로 편하고 즐겁게 지내기 위하여 지켜야 할 일을 알아보고, 실천해 봅시다.

\section{움직이지 않는 차들}

상진이네 가족이 타고 있는 차가 시내로 접어 들자, 도로에는 많은 차들이 있었습니다. 모든 차들은 신호에 따라 물결처럼 오고 갔습니다.

어느덧 상진이네 차는 복잡한 시내를 벗어나 서, 시골길로 접어들었습니다. 시골길에는 신호 등도 많지 않고 차도 많지 않았습니다. 차창으로 불어 오는 맑은 공기에 봄내음이 느겨졌습니다.

작은 댁에 거의 다 와서였습니다. 상진이네 앞 의 차들이 전혀 움직이지 않는 것이었습니다.

'도대체 무슨 일로 이렇게 여러 사람들을 기다 리게 하는 것일까??

사람들이 차에서 내려 앞으로 걸어가는 것이 보였습니다.

상진이 아버지께서도 차에서 내려 앞쪽으로 가 보셨습니다. 상진이도 궁금해서 아버지를 따라갔 습니다.

길이 좁아지는 곳에 두 대의 자동차가 서로 부딪쳐 부서진 채로 서 있는 것이 보였습니다.

왜 이런 교통 사고가 일어나게 되었을까요?

\& 두 차의 운전자들은 어떻게 하였어야 옳은지 이야기해 봅시다.

우리는 왜 공중 도덕을 지켜야 할까요

우리는 여러 사람들과 함께 살고 있습니다.

그 가운데는 우리와 친한 사람도 있지만, 잘 모르는 사람도 있습니다. 그 모든 사람과 더불어 살아가야 합니다.

그런데 사람들이 제각기 마음대로 행동한다면 어떻게 될까요? 어떤 사람이 쓰레기를 아무 데 나 함부로 버린다면, 그 주변은 온통 쓰레기장이
될 것입니다.

수돗가에서 여러 사람이 줄을 서서 기다리는 데 한 사람이 늦게 와서 새치기를 한다면, 다른 사람들은 그만큼 더 오랫동안 기다려야 할 것입 니다.

여러 사람과 더불어 살아가기 위해서는, 무엇 보다도 다른 사람에게 피해를 주거나 불편하게 하지 않도록 서로 노력해야 합니다.

여러 사람이 함께 이용하는 공공 장소에서 큰 소리로 떠들거나 뛰어다녀서는 안 됩니다. 또, 여러 사람이 함께 사용하는 시설을 함부로 다루 어서 더럽히거나 고장나게 해서도 안 됩니다.

그리고 작은 일이라도 다른 사람에게 피해를 주거나 불편하게 하여서는 안 됩니다. 피해를 주 거나 불편하게 하였을 때에는 반드시 사과를 해 야 합니다.

더 공부할 문제

- 교실에서 친구들에게 불편을 끼친 일이 있으 면 말해 봅시다.

- 우리가 지켜야 할 공중 도덕에는 어떤 것이 있는지 알아 봅시다.

3 학년 2학기 교과서에 나와 있는 '모두가 소중한 사 람은 사람 차별하지 않기로서, 직접적으로 준법 정신 을 다루고 있지는 않지만 법의 근본 정신인 인간 존 중을 다루고 있다. 특히 제시된 다음의 문제 사태는 힘에 세다고 다른 친구들을 괴롭히는 어린이의 시례 를 통해 우리 사회의 폭력 문제와 법과의 관계를 생 각해 볼 수 있다.

힘이 센 성민이

철호와 성민이가 땀을 뻘뻘 흘리며 씨름을 하 고 있었습니다.

“철호야, 다리를 걸어! 힘을 더 내!" 아이들은 큰 소리를 지르며 철호를 응원했습 니다.

"철호, 이겨라! 철호, 이겨라."

그러나 성민이를 응원해 주는 아이는 별로 없 
었습니다.

두 아이가 서로 밀고 당기다가 성민이가 힘을 주는 순간, 철호가 뒤로 넘어졌습니다.

아이들은 실망의 빛을 감추지 못했습니다. 성 민이는 으스대면서 아이들을 둘러보았습니다. 그 러자 갑자기 조용해졌습니다.

"너희들, 앞으로 내게 덤벼들 생각하지마!"

성민이는 이렇게 말하며, 철호의 어깨를 툭치

고 운동장 저 쪽으로 가 버렸습니다.

힘이 센 사람은 약한 사람을 무시해도 될까 요? 그래서는 안 된다면, 그 이유는 무엇인 지 말해 봅시다.

위의 사례는 '법보다 주먹이 가깝다'는 세태를 생각 해 볼 수 있는 소재로서, 법을 지키기 위해서는 용기 가 있어야 함을 시사해준다. 그러면서 기본적으로 다 른 사람을 존중할 때 나도 다른 사람들로부터 존중받 는다는 정신을 가르치고 있다.

\section{나. 4 학년}

4 학년 도덕 교과서의 법교육 관련 내용은 1 학기 5. 이해하고 존중하는 마음과 2 학기 5 . 용기있는 생활이 다. '이해하고 존중하는 마음'의 지도 요소는 다른 사 람의 이익 존중으로서, 다른 사람에게 피해를 끼치지 않고 서로 도와가며 생활하는 소극적인 준법 정신을 다루고 있다. 다음의 예에서 잘 나타나 있다.

우리는 여러 사람들과 함께 살아갑니다. 여럿 이 함께 살아가려면, 법과, 규칙을 지키고 다른 사람의 인격을 존중해 주어야 합니다.

다른 사람에게 피해를 주지 않고 서로 도와 가면서 생활하려면, 우리가 어떠한 마음가짐을 가져야 하는지 생각해 봅시다.

자기 생각만 하는 철호

철호는 자기가 편한 대로만 행동합니다.

"예, 철호야! 모두 열심히 청소하는데 너만 그
렇게 놀고 있으면 어떡해! 놀 때는 놀더라도 청 소할 때는 우리 함께 하도록 하자."

같은 반 친구가 하는 말에도 철호는 들은 척도 하지 않습니다.

"철호야, 그렇게 제멋대로 행동하는 법이 어디 있니? 청소는 너도 해야 할 일이잖니?"

다른 친구가 나서서 말하면 그 때서야 퉁명스럽 게 대답합니다.

"너희들은 무슨 말이 그렇게 많니? 어떻게 하 든지 그건 내 자유야. 내가 하고 싶은 대로 하는 것이 자유라고."

철호는 심술궃기로 이름이 나 있습니다.

선생님께서 오시면 얼른 청소를 하는 척합니 다. 그렇지만 청소를 제대로 하지는 않고 비를 들고 왔다 갔다 하기만 합니다.

철호는 친구들의 기분은 생각하지도 않습니다. 함부로 거친 말을 하거나 별명을 지어 부르면서 친구들을 놀려 댑니다. 친구들이 모두 속상해하 여도 철호는 아랑곳하지 않습니다.

철호는 욕심쟁이이기도 합니다.

자기의 물건을 가방에 넣어 두고 다른 친구들 의 물건을 빌려 씁니다. 누가 자기의 자리에 앉 으면 내 자리라고 떠밀어 냅니다. 무엇이든지 가 장 좋은 것만을 가지려고 고집을 부립니다.

3 철호처럼 행동한 일이 있었는지 생각해 봅시다.

s 철호와 같은 행동을 하는 친구들을 보면 어 떤 생각이 드는지 이야기해 봅시다.

\& 내가 하고 싶은 대로 하는 것이 자유인지 자 기의 생각을 발표해 봅시다.

위의 사례에서 제시된 질문들은 학생들로 하여금 자신의 생활을 반성하고 함께 토의해보게 하여 법의 식을 내면화하는 데 도움을 준다고 하겠다. 또한 다음 의 ‘더 공부할 문제’는 법과 규칙을 마지 못해 지킨다 는 자세를 넘어서 다른 사람을 존중해야 한다는 적 극적인 태도를 심어줄 수 있는 내용이다.

$$
\text { 더 공부할 문제 }
$$

노란 카드는 축구 경기에서 규칙을 위반한 
선수에게 주는 경고장입니다.

- 일상 생활에서도 노란 카드가 필요합니다. 아 래 글을 읽고, 느낀 점을 발표하여 봅시다.

"철수야 이것 받아." 받아보니 경코 카드였습니다. 복도에서 뛰어다닌 철수는 그것을 건네 준 영희를 쳐다보았습니다. 예쁜 영희가 생글생글 웃으며 말하였습니다. "읽어 보고 조금만 생각해 봐." 그 카드에는 이렇게 적혀 있었습니다.

함께 공부하는 친구들을 위해서 너는 무엇을 할 수 있지?

1 학기 교과서에 비해 2학기의 '용기있는 생활은 더 욱 적극적인 법의식을 가르치고 있다. 이 제재의 지도 요소는 정의감과 용기로서, 법과 규칙을 지키는 일은 곧 정의로운 것이며 정의를 위해서는 때로 용기가 필 요하다는 점을 보여준다.

\section{영호의 용기}

민호는 공부를 마치고 운동장으로 나왔습니다. 운동장에는 많은 아이들이 놀고 있었습니다. 이 웃에 사는 2 학년 영희도 친구들과 어울려 공을 가지고 누가 멀리 던 질 수 있는지 내기를 하고 있습니다. 영희가 친구들을 향해 공을 힘껏 던졌 습니다.

그 때였습니다. 기운이 센 상우가 어디에선가 나타나 공을 잡더니, 여러 아이들 속으로 달아났 습니다.

“공 줘!"

공을 되찾으려고 영희와 2 학년 여자 아이들이 쫓아다니자, 상우는 더욱 신이 났습니다. 상우는 공을 높이 찼다가 다시 달려가서 받고, 요리조리 튀기면서 영희를 놀렸습니다.

"오빠는 비겁해!"

영희가 울면서 이렇게 말했습니다.

"다시 말해 봐."
"왜 약한 사람을 괴롭혀?"

상우는 공을 주는 척하면서 공을 머리 위로 던지고 달려가 받으며 계속 놀렸습니다.

"오빠, 약한 사람을 괴롭히는 것이 그렇게 재 미있어?"

민호는 상우에게 달려가 어린 동생들을 괴롭 히지 말라고 말하고 싶었으나, 용기가 나지 않았 습니다.

영희가 민호를 보고 도움을 청하였습니다.

"민호 오빠, 저 공을 좀 뺏어 줘?"

민호가 영희의 말을 듣고도 우물쭈물하고 있 는 사이에, 옆에 있던 영호가 쏜살같이 달려갔습 니다. 영호는 상우가 높이 던져 올린 공을 먼저 잡았습니다.

"영호 너, 가만 두지 못해."

상우는 화를 내며 영호에게 달려들었습니다.

"이 공이 네 거야?"

"네가 문데 상관이야!"

상우는 공을 빼앗으려 하였습니다. 영호는 공 을 옆구리에 낀 채 뒷걸음을 쳤습니다.

$$
\text { 다. } 5 \text { 학년 }
$$

5 학년 도덕 교과서에는 직접적인 법교육 내용이 제 시되어 있으며, 다른 사람의 권리 존중과 합리적인 문 제 해결 방법이 포함되어 있다. 먼저 직접적인 법교육 내용은 5. 우리의 생활과 법이다. 이 제재에서는 우리 가 법과 규칙을 지켜야 하는 까닭이 무엇이며, 법과 규칙을 지키는 올바른 태도를 다루고 있다.

법을 지켜야 하는 까닭

이 세상은 나 혼자만 사는 것이 아니고, 여러 사람들과 더불어 함께 살아간다. 그렇기 때문에 내 마음대로만 행동하거나 남을 괴롭히고, 피해 를 주어서는 안 된다. 내가 다른 사람으로부터 피해를 받기 싫은 것처럼, 다른 사람도 나 때문 에 피해를 받고 싶어하지 않는다.

때로는 법을 지키는 일이 귀찮고 손해를 보는 것 같은 생각이 들기도 한다. 그렇다고 해서 사람 
들이 모두 '나 하나쯤이야'하는 생각에서 멋대로 행동한다면, 우리 사회는 어떻게 되겠는가?

법과 규칙은 사람들이 서로 피해를 받지 않고 함 께 살아가기 위하여 정해 놓은 기준이다. 다시 말 해서, 그것은 사람들이 질서를 유지함으로써 행복 하고 안전하게 살아가도록 하기 위한 것이다.

민주 사회의 법과 규칙은 우리가 뽑은 대표들 이 만든 것이기 때문에, 우리들 자신이 만든 것 이나 다름이 없다. 그러므로 법과 규칙을 우리가 지켜야 하는 것은 너무나 당연한 일이다.

위의 규범 설명은 도덕과 교육에서의 법교육과 사 회과 교육에서의 법교육의 차이점을 보여 준다. 사회 과 교육에서도 법의 근본 문제와 이념에 대하여 다루 고 있지만 대체로 법의 현실 적용 문제와 법률 관계 그리고 헌법, 민법 등 구체적인 실정법의 내용을 중심 내용으로 삼고 있는데 비하여, 도덕과 교육에서는 법 의 연원과 법에 대한 우리의 시각을 중시한다. 나아가 실정법상으로 문제가 없다 하더라도 자신의 양심에 의한 판단을 이울러 고려하고 있다. 즉 자연법적인 사 고를 아울러 중시하는 것이다. 다음의 사례가 이를 잘 말해 준다.

나의 선택

체육 시간에 1 반과 축구 경기를 하기로 했다. 지난번 경기에서 우리 반에게 졌던 1 반이 다시 도전한 것이다.

드디어 경기가 시작되었다. 지난번에 졌던 1 반 이 먼저 공격했다.

두 팀의 실력이 팽팽했다. 1 반 선수들을 그 동 안에 연습을 많이 한 것 같았다. 응원하는 소리 는 점점 커갔지만, 전반전에는 두 팀 모두가 득 점 없이 비겼다.

그러나 후반전에서도 좀처럼 승부가 나지 않 았다. 나는 점점 초조해졌다.

경기가 거의 끝날 무렵에 드디어 좋은 기회가 왔다. 수비를 맡았던 수창이가 상대방의 공을 가
로채서 1 반 진영에 서 있던 나에게 넘겨 주었다. 나는 재빠르게 가슴으로 공의 방향을 바꾸었다. 그 순간, 공이 내 손을 살짝 스쳤으나 아무도 나 의 반칙을 눈치채지 못했다.

나는 잠시 멈칫거렸지만, 곧 1 반 골문 앞으로 공을 몰고 갔다. 상대편의 수비를 ㄸㄸㅀㄱㅗ 골키퍼와 마주 섰다. 1 반의 골키퍼가 놀라서 앞으로 뛰어 나왔다. 그 순간에 나는 골문으로 살짝 공을 차 넣었다. 골인이었다. 드디어 $1: 0$ 이 되었다.

. . . . . . .

‘손에 공이 닿았는데...... 아니야. 아무도 보지 않았는데 $\cdots . . . .$. 누구라도 나처럼 했을 거야.

그렇지 않아. 본 사람이 없다고 모든 사람이 나처럼 한다면, 이 세상에 규칙이라는 게 있을 필요가 없잖아."

\& 내가 만약 병수와 같은 처지면 어떻게 했을 지 생각해 보자.

\& 법과 규칙을 지키는 올바른 태도는 어떠해야 하는지 토의해 보자.

다음의 시례는 학생들의 법태도를 강화시키기 위하 여 제시된, 법을 잘 지킨 사람의 모범 시례들이다.

누구에게나 똑같은 법

처칠과 교통 경찰

하루는 영국 처칠 수상이 국회에 나가서 연설 하게 되었는데, 손님을 맞이하다가 시간이 늦었 다. 그래서 어떻게 해서라도 예정된 시간 안에 도착하도록 운전 기사에게 일렀다.

바쁘게 가는 도중에, 운전 기사는 제한 속도보 다 빨리 차를 몰았다. 교통 경찰관이 달려와서 차를 세웠다. 그러자 운전 기사는 당연하다는 듯 이 말했다.

"수상 각하의 차요. 지금 국회로 가는 길인데, 시간이 늦어서 급히 가는 중이오."

그러나 교통 경찰관은

"수상 각하를 닮긴 닮았는데, 처칠 경의 차가 교통 규칙을 위반할 리 없소. 면허증을 내놓고 
내일까지 경찰서로 출두하시오."

라고 말하면서, 운전 기사를 교통 법규 위반으로 적발하였다.

처칠은 교통 경찰관이 자기의 직무를 수행하 는 태도에 깊은 감명을 받았다.

임금의 사촌을 가둔 이내

이내가 대사헌이라는 직책을 맡고 있을 때, 태 종 임금의 사촌 이백온이 사람을 죽인 사건이 일어났다. 임금은 이백온이 자신의 사촌이라고 해서 죄를 용서해 주려고 했으나, 이내는 안 된 다고 주장하였다.

"옛날에는 임금의 아버지라도 살인을 하면 임 금의 권한으로도 용서하지 못했습니다. 그러므로 이백온의 사건도 법대로 처리하여 죽은 사람의 넊을 위로해야 합니다."

태종 임금도 이내의 성격을 잘 알고 있었으므 로, 마지못해 이백온을 귀양 보내도록 하였다. 이내는 이백온을 묶어 호위를 엄하게 하여 귀양 지로 보냈다.

자신의 시촌을 묶었다는 말을 들은 태종의 노여 움은 대단했다. 그래서 그 일에 관계했던 사람들을 옥에 가두었다. 이내는 임금에게 이렇게 아뢰었다.

"백온의 형이 사람을 죽인 일이 있는데, 백온 도 살인을 했습니다. 그를 묶어 보낸 것은 도망 갈까 염려되어 그런 것이며, 다른 뜻이 있어서가 아니었습니다."

"그대는 나의 신하가 아니더냐? 어찌 임금인 나의 종친을 그렇게 욕보일 수 있단 말이냐?"

"이는 전하의 종친을 욕보이는 게 아니라, 전 하의 정치를 돕는 도리라고 생각합니다. 누구라 도 법을 지키도록 하는 일은 전하의 정치를 돕 고, 나아가서는 나라도 살리는 길입니다." 이내는 끝까지 자기 뜻을 굽히지 않았다.

\& 내가 교통 경찰관이나 이내라면 어떻게 했을 지 이야기해 보자.

\& 누구든지 나라의 법을 지켜야 하는 까닭을 이야기해 보자.
법을 적용하는 데 공정하지 못하다면, 어떤 일이 생기게 될지 이야기해 보자.

\section{더 공부할 문제}

0 주변에서 법이나 규칙을 지키지 않는 사람을 보았을 때, 우리가 어떻게 하는 것이 좋을지 생각해 보자.

위의 예화들은 외국의 시례와 우리 나라의 시례를 각 각 하나씩 소개하고 있다. 이러한 의도는 우리 나라 사 람들은 외국 사람들에 비해 법을 잘 지키지 않는다는 일반적인 선입견을 없애기 위한 것이라 볼 수 있다.

또한 더 공부할 문제에서는 자기 자신이 법을 잘 지켜야 한다는 자세를 넘어서 다른 사람이 법을 지키 지 않는 경우를 보았을 때 신고나 고발을 해야함을 강조한다. 사실 우리는 남의 잘못을 감싸주는 것을 미 덕으로 생각해왔고, 학교에서도 친구의 잘못을 고자질 하는 일은 좋지 못한 행동으로 간주되어 왔다. 그러나 이러한 관습에 의해 우리의 법의식이 약하다고 볼 수 있으며, 이 제재의 더 공부할 문제는 신고나 고발 정 신에 대해 다시 한 번 생각해 볼 수 있는 기회를 제 공한다.

5 제재의 내용이 직접적인 법교육이라면, 6. 사람의 기본 권리는 법의 연원 또는 법의 근본 이념을 가르 치는 내용이라 할 수 있다. 사람들은 생긴 모습이나 생각하는 것이 각기 다르지만, 누구나 똑같이 소중한 존재로서, 모든 사람은 누구나 평등하게, 그리고 인간 답게 살아갈 권리가 있다는 것이다. 6. 사람의 기본 권리의 내용을 보면 다음과 같다.

\section{우리는 모두 소중한 존재}

사람들이 만약 서로 무시하고 놀린다든지, 힘 이 세다고 약한 사람들을 함부로 때리고 괴롭힌 다면 어떻게 할까? 그러한 사회 속에서는 어는 누구도 마음 편하게 살 수 없을 것이다.

사람은 누구나 존엄하다. 그 사람이 힘이 세거 나 약한 것과 상관없이, 돈이 많거나 가난한 것 과 상관없이, 그리고 그 사람이 신체적으로 장애 가 있든 없든 모든 사람은 존엄하다. 
그러므로 사람은 인격적으로 대우받을 권리가 있으며, 동시에 다른 사람의 권리를 존중해야 하 는 의무가 있다. 이는 모든 사람이 평등하게 인 격적인 존재로 살아가고, 서로 존중받는 사회를 만드는 길이다.

그럼에도 불구하고 우리는 자칫하면 자신의 권리만을 주장하고, 남의 권리를 무시하거나 소 홀히 생각하기 쉽다. 친구의 주장이 자기와 다르 다고 그 말을 비웃는다면, 그것은 친구의 권리 행사를 방해하는 것이다.

우리는 모두 다른 사람들을 자기와 똑같이 소 중한 존재로 생각하고,상대방의 권리를 존중할 줄 알아야 한다.

\section{권리 존중}

언제나 함께 놀아 주고 이야기도 많이 해 주 시는 삼촌께서 오셨다. 삼촌은 민영이에게 학교 생활에 대해 물으셨다.

"학교 생활은 재미있니? 내가 학교에 다닐 때 에는 까닭없이 친구를 때리거나 못살게 구는 어 린이가 더러 있었는데, 요즈음에도 그런 아이가 있니?"

"네, 기끔 있어요."

"내가 5 학년 때에 키가 제일 크고 힘이 센 철기 라는 아이가 있었지. 그 애는 다른 아이들을 특 별한 이유도 없이 때렸단다. 친구의 물건도 자기 마음에 들면 빼앗아 갔지."

"그런데도 그런 짓을 못 하게 아무도 말리거 나 충고를 하지 않았나요?"

"철기가 무서워서 그렇게 할 수가 없었지."

"마치 책에서 읽은 동물 나라의 이야기 같군 요."

"우리 민영이가 정말 똑똑하구나. 사람들의 세 계에서도 과거에는 그러한 일들이 많이 있었지. 권력을 가지거나 돈이 많은 사람들이 가나하고 힘이 약한 사람들을 함부로 감옥에 가두거나 재 산을 빼앗고 죽이기도 했지. 또 백인들이 흑인들 을, 남자들이 여자들을 차별하는 일도 있었단다.
그러한 사회에서는 힘없는 많은 사람들이 억울 한 일을 당하면서 고통스럽게 살아가지 않으면 안 되었지."

"그러나 이제는 그렇지 않지요?"

"아직도 이와 비슷한 나라들이 더러 있단다. 그러나 우리 나라는 민주 국가로서 모두가 똑같 이 자유롭고 평등하게 살아가려고 노력하고 있 지. 사람들은 성격이나 능력, 성별과 인종 등 여 러 가지 측면에서 서로 다른 점이 많지. 그러나 그들은 하나하나가 모두 똑같이 소중한 사람들 이란다. 어떤 사람도 다른 사람보다 더 귀중하거 나 덜 귀중하다고 할 수 없지.

이렇게 사람들에게는 모두 인간다운 대접을 받으면서 행복하게 살아갈 권리가 있지. 그것 을 인간의 기본 권리라고 한단다. 민주 사회 에서 시민은 누구나 똑같이 그러한 권리를 가 지고 있고, 다른 사람도 자기와 똑같이 기본 권을 가지고 있기 때문에 서로서로 존중해야 한단다."

"그러한 권리에는 어떤 것들이 있는지 자세히 알고 싶어요."

"매우 많지, 다 애기하기는 어렵지만, 생각나 는 대로 몇 가지만 살펴보면, 신체의 자유를 누 릴 권리, 자유롭게 자기의 생각을 표현할 권리, 자기의 재산을 남에게 빼앗기지 않을 권리 등이 있단다.

또 공부를 잘 하든 못 하든, 여자든 남자든, 가난하든 부자든 그러한 이유 때문에 다른 사람 으로부터 차별을 당하지 않을 권리도 있지."

민영이는 삼촌과 애기를 하면서 권리가 무엇이 며, 우리들이 왜 상대방의 권리를 존중해야 하는 가에 대하여 알게 되었다.

\& 권리가 존중되지 않는 사회에서는 어떤 일이 일어날지 생각해 보고, 모든 사람들의 권리가 똑같이 지켜지려면 어떻게 해야 할 것인지 토론해 보자.

\& 삼촌과 민영이의 대화를 읽고 나서, 사람의 권리에 대하여 어떤 생각을 하였는지 이야기 해 보자. 


\section{라. 6학년}

6학년 도덕 교과서에서도 직접적인 법교육 내용이 제시되어 있다. 지도 요소는 법의 정신 이해로서, 5 학 년의 법을 지키는 태도를 심화하는 내용이다. 특히 이 제재 (5. 법을 지키려는 마음)에서는 법의 필요성과 준법 정신을 설명하고 나아가 준법을 초월한 자연법 사상을 다루어 법실증주의와 자연법 사상의 조화를 모색하고 있다.

법의 필요성과 준법 정신

사람들이 사회를 이루어 함께 살다가다 보면, 서로 이해 관계가 대립되거나 갈등도 있게 마련 이다. 사람들이 모두 자기의 이익만을 내세우고 권리만을 주장할 경우, 사회는 무질서와 혼란에 빠질 것이고, 강한 자만이 살아남게 될 것이다.

이와 같은 무질서를 바로잡고 모든 사람이 평화 롭게 살아가는 사회를 만들기 위해서는 누구든 지 반드시 지켜야 하는 공평한 법과 규칙이 있 어야 할 것이다. 이것은 마치 운동 경기에 규칙 이 필요한 것과 마찬가지라고 하겠다.

우리가 살아가는 데 따라야 할 규범에는 법 이외에도 도덕이 있다. 도덕에 어긋나는 행동을 하면 사회적인 비난을 받게 되고, 법을 어길 경 우에는 일정한 처벌이나 불이익을 받게 된다. 그 러므로 법은 도덕보다 더 강제성을 갖는 규범이 라 할 수 있다.

그러나 법의 목적은 처벌하는 데 있는 것이 아니라, 사람들 간의 대립과 갈등을 공정하게 해 결하는 데 있다. 따라서, 법은 두려워하거나 멀 리해야 할 것이 아니라, 사람들 간의 원만한 관 계를 유지하기 위해 모두가 알고 지켜야 하는 것이다. 법이 있어야 모두가 보호받을 수 있고, 모든 사람의 권리와 이익이 공정하게 보장받을 수 있다.

공평한 법이 만들어지고 그것이 모든 사람에 게 공정하게 적용됨으로써 질서를 이루는 사회 나 국가를 법치 사회 또는 법치 국가라고 한다. 힘이나 돈에 의해서가 아니라, 법에 의해서 다스
려지는 법치 사회는 살기 좋은 사회의 기본 조 건이라 할 수 있다.

그러나 좀더 바람직한 것은, 문제가 법에 의해 서 해결되기보다는 그에 앞서 도덕적으로 해결 되는 도덕 공동체를 이룩하는 일이다.

법 없이도 살 사람

저녁상을 물린 후, 할머니와 아버지께서는 고 향 사람들에 대한 이야기를 나누고 계셨다. 할머 니께서 안타까운 표정으로 말씀하셨다.

"예, 아범아. 영선이 아비 말이다. 1년 농사를 헛지었다더구나. 그 사람은 법 없이도 살 사람인 데, 정말 안됐어."

그 이야기 중에 내가 이해하지 못한 것이 있 어 아버지께 여쭈어 보았다.

“할머니께서 “법 없이도 살 사람이라고 하셨 는데, 그게 무슨 뜻이에요?

그러자 아버지께서 말씀해 주셨다.

"대부분의 사람들은 법에 따라 살기에 앞서, 자기 양심에 따라서 착하고 성실하게 살고 있단 다. 그와 같이 자기의 양심에 따라 자율적으로 살면서 자신의 본분을 다하는 사람을 '법 없이도 살 사람이라고 한단다. 사회가 그런 착한 사람 들로만 이루어진다면 얼마나 좋겠니?"

“하지만, 이 세상에는 그와 같이 착한 사람을 이용하거나 괴롭히는 나쁜 사람들도 있잖아요? 그 아저씨의 돈을 빌려 가서 갚지 않는 사람처 럼요."

"그렇지. 그런 사람들 때문에 도덕만으로는 사 회 질서를 유지하기에 충분하지 않단다. 그래서 법과 같은 강제성이 있는 규범을 정해 놓고 모 두가 이를 지키게 하지. 그리고 법을 어겼을 경 우에는 그에 합당한 처벌을 받게 된단다."

"그러니까 법 없이도 살 수 있는 착한 사람의 권리와 이익을 보호하기 위해서도 법이 필요하 겠군요."

"바로 그렇단다. 이제 보니 우리 아들이 제법 생각이 깊어졌구나." 
아버지와 나의 대화를 듣고 계시던 할머니 께서는 대견하다는 듯이 내 머리를 쓰다듬어 주셨다.

나는 잠자리에 들어서도 조금 전에 아버지와 대화를 나누었던 법에 대해서 곰곰이 생각해 보 았다. 만일, 우리들이 살고 있는 사회에 법이 없 다면, 어떻게 되었을까?

\section{3. 중학교 도덕 교과서의 법교육 내용}

중학교 도덕 교과서에는 $1,2,3$ 학년에 모두 법교육 및 관련 내용이 포함되어 있다. 1학년에서는 개인 생 활 영역과 사회 생활 영역에, 2,3 학년에서는 사회 생 활 영역에서 다루어지고 있다.

\section{가. 1학년}

1학년 도덕 교과서에는 개인 생활 영역인 1. 삶과 도덕 - 1. 인간의 삶과 도덕에서 사회 규범으로서 법 과 예절과 도덕의 공통점과 차이점, 그 관계를 설명하 고 있다.

법과 예절과 도덕

선생님 : 지난 시간에 우리는 도덕적인 생활의 기반이 되는 양심에 대하여 배운 바 있 습니다. 오늘은, 우리의 도덕 생활과 깊 은 관련이 있는 법과 예절에 대해서 알 아보도록 하겠습니다. 도덕과 법, 그리 고 예 걸은 우리가 지켜야 한다는 점에 서는 서로 같지만, 실은 다른 저도 있습 니다. 이 셋은 어떻게 다를까요?

민 수 : 우리는 꼭 지켜야한 하며 지키지 않으 면 나쁜 일이 되는 것은 도덕이고, 그 것을 지키지 않는다면 처벌을 받게 되 는 것이 법입니다. 그리고 지키지 않으 면 상대방에게 불쾌감을 주는 것이 예 절입니다.

선생님 : 민수가 좋은 이야기를 해 주었군요. 내가 보기에, 민수의 이야기 중에 특히 중요한
말이 하나 있습니다. "법을 지키지 않으 면 처벌을 받는다."라는 말입니다. 그렇 다면 도덕이나 예절을 지키지 않는 사람 은 어떻게 되나요? 처벌을 받게 되나요?

학생들 : 아니오.

인 숙 : 도덕이나 예절을 지키지 않았다고 해서 처벌을 받아야 하는 것은 말도 안 되는 일입니다. 법을 어긴 사람을 처벌하게 되 는 것은 당연하지만, 예절을 좀 지키지 않았다고 해서 처벌하게 되면 어떡해요? 그럼 저는 벌써 여러 번 처벌을 받았겠 네요.

학생들 : (웃음)

정 수 : 저는 지금, 국어 사전에서 도덕과 법, 그리고 예절이란 낱말을 찾아보았습니 다. 그 설명이 좀 어렵기는 하지만, 선 생님의 말씀과 비슷합니다.

선생님 : 자 지금까지 토의된 바를 중심으로 하 여, 법과 예절과 도덕의 관계에 대해서 정리해 보도록 하겠습니다. 법은, 인간 사회에서 서로 지키지 않으면 상대방에 게 신체적, 물질적, 정신적으로 커다란 피해가 예상되는 일이 있을 때, 그러한 내용을 다스리는 규범입니다. 예컨대, 남에게 재산상의 손해를 입히거나 신체 적으로 고통을 주게 되면, 법에 의해서 처벌을 받게 됩니다.

법과 예절 도덕은 모두, 우리가 이 세상을 살 아가면서 지켜야 할 바를 잘 가르쳐 줍니다. 예 절을 지킴으로써 주변 사람들과의 조화 속에서 살아갈 수 있습니다. 법을 지킴으로써 서로 간의 갈등이나 마찰을 피하고 불안을 없앨 수 있으며, 도덕을 지킴으로써 근본적으로 착하고 바른 삶 을 스스로 실현할 수 있습니다.

위의 설명과 함께 1 학년 교과서에는 사회 생활 영 역인 III. 사회와 도덕 - 3. 현대 사회와 공중 도덕 단 원에서 사회 질서 유지와 공동의 이익 문제를 초등학 
교 5 학년에서 다루었던 신고와 고발 정신도 언급하고 있으며, 내용 제시 방식은 사진 자료(나 하나쯤이야 하는 생각 때문에 버려진 우리의 환경)와 함께 설명 문으로 되어 있다.

여러 사람들이 모여 사는 사회 생활에서 개인의 행 동은 반드시 나 아닌 다른 사람에게도 영향을 끼치게 마련이다. 그러므로 나만의 이익을 위하여 다른 사람 에게 폐를 끼치거나, 다른 사람들이 나쁜 짓을 하는 것을 보고도 그냥 못 본 체하는 것은, 그 사회의 질서 유지와 발전을 위해 바람직한 것이라고 볼 수 없다.

요즘 우리 사회에서 많이 이야기되고 있는 환경 문 제만 해도 그렇다. 만일, 어떤 공장에서 남이야 어떻 게 되든 나만 돈을 많이 벌면 된다는 그릇된 생각으 로, 공해 방지 시설을 갖추지 않아 매연을 내뿜는다든 가 폐수를 그대로 흘려 버린 다면, 그 공장 부근에 사 는 많은 사람들의 안전과 건강을 해치게 된다. 또, 어 느 전기 기술자의 태만이나 실수로 캄캄한 밤 중에 1 시간 이상 정전이 되었다고 가정해 보자. 마을은 온통 암흑 세계가 되고, 그렇게 되면 각 가정이나 공장에서 는 얼마나 많은 불편과 손실을 입게 될 것인가?

\section{나. 2학년}

2학년 도덕 교과서에서는 사회 생활 영역인 III. 현 대 사회와 도덕 문제 - 3. 사회적 도덕 문제의 등장 과 해결에서 법교육을 다루고 있다. 여기서는 도덕과 법과의 관계를 생각해보고, 또한 불의를 보고도 이를 시정하지 않으면 정의가 실현되기 어려우며 정의를 지키기 위해서는 용기가 필요함을 보여주고 있다.

여러 가지 사회적 도덕 문제

다섯째, 지나친 개인주의로 인하여 다른 사람 이나 사회에 대한 무관심과 고발 정신이 부족한 것도 우리가 당면한 사회적 도덕 문제이다. 현대 시민 사회는 개인의 사생활을 존중해준다. 그러 나 이것이 지나쳐서, 다른 사람의 일에 관심을 가지지 않을 뿐만 아니라, 사회 문제에 무관심한
경우가 많다. 또, 불의를 보고도 아무도 이것을 바로잡으려 하지 않아 사회의 정의가 훼손되는 경우도 많다.

경수는 청소를 끝내고 집으로 가고 있었다. 학 교 뒷담을 돌아서는데 한 청년이 광고지를 학교 담에 붙이고 있었다. 학교 담에는 이미 여러 가 지 광고지가 덕지덕지 지저분하게 붙어 있었다. 경수는 광고지를 붙이고 있는 청년에게 그러지 말라고 하고 싶었으나, 피해가 올 것 같아 모르 는 체하고 지나쳐 버렸다.

위의 예화는 초등학교 4학년 교과서의 '영호의 용 기'와 같이 정의감과 용기의 관계를 보여주고 있다. 그리고 사회적 도덕 문제는 서로 동떨어진 문제가 아 니며 서로 긴밀하게 연관되어 있으며, 각 문제의 해결 역시 전체적인 사회적 도덕 문제의 테두리 안에서 이 루어질 수 있음을 강조하고 있다. 그리고 사회의 도덕 문제를 해결하는 방법으로서 법을 지키는 일과 아울 러 공동체 의식과 연대성을 제시한다. 이러한 시각은 곧 실정법을 지키는 수준을 뛰어넘는 자연법적 사고 라 할 수 있다. 다음의 예화를 보자.

지난 수십 년간 우리 나라는 고도의 경제 성 장을 이룩했다. 물질적 풍요를 위해서 모든 힘을 바치고 이에 따른 불편이나 어려움을 참아 왔다. 개인과 사회를 막론하고 어느 정도 기본적인 욕 구가 만족되면 더 높은 단계의 욕구를 가지게 마련이다.

……

다음 이야기를 읽고, 사회적 도덕 문제의 해결 에 대하여 생각해 보기로 하자.

김사장은 학용품을 생산하는 공장을 운영한다. 그는 가내 수공업으로 사업을 시작하여 종업원 이 몇십 명이나 되는 제법 규모있는 공장을 이 루어 놓았다. 그러나 김사장은 요즈음 커다른 갈 등에 빠지게 되었다. 순조롭게 운영되던 사업이 점점 어렵게 되고 있는 것이다. 급하게 자금을 구하기 위해 동분서주하는 경우가 잦아지고, 종 
업원들이 힘들고 따분한 작업을 하려 하지 않게 때문에 종업원을 구하기가 어렵게 되었다. 또, 수입 개방으로 외국 학용품이 들어와서 판매가 점점 더 어렵게 되었다.

그런데 이러한 어려움보다 김사장의 마음을 흔 들어 놓고 힘이 빠지게 하는 것은, 같은 업종의 공장을 운영하다 그만두고 지금은 부동산으로 많 은 돈을 번 친구의 경우이다. 그 친구는 몇 년전 부동산 값이 오르기 시작하자, 사업을 정리하고 몇 군데 건물과 따을 사서 되팔아 많은 이익을 남겼다. 그 친구는 김사장을 볼 때마다 "지금도 늦지 않았으니, 어렵고 힘든 사업을 걷어치우고 부동산에 투자해 쉽게 돈을 벌어 보라."고 권한 다. 이러한 말을 들을 때마다 김사장은 "그것은 옳지 못하다"고 하면서 친구와 언쟁을 벌이곤 한 다. 그 친구는 정부에서 부동산 투기를 억제하기 위해 여러 가지 규제를 만드는 것은 잘못이라고 말한다. 개인의 재산인 부동산을 사고 파는 것은 개인의 권리이며 자유라는 것이다. 그리고 이것 이 다른 사람에게 직접적인 피해를 주는 것이 아 니기 때문에 개인의 양심에 맡겨야 한다고 주장 한다. 그러나 김사장은, "친구의 행위는 잘못된 것이며 이것은 사회 전체에 나쁜 결과를 가져 오 므로 반드시 막아야 한다'고 생각한다.

사회적 도덕 문제는 인간의 사회 생활 과정에서 일 어나는 문제로서, 사회 생활의 여러 분야에서 나타나 며, 그 해결도 경우에 따라 다르다. 사회적 도덕 문제 의 해결은 사회 구성원 개인의 양심이나 도덕적 판단 보다는 사회적 제도나 규칙을 통하여 해결해야 하는 경우가 많다.

그러나 제도와 규칙만으로 사회적 도덕 문제를 모 두 해결할 수 있을까? 사회 구성원들의 양심에 의한 판단이나 도덕 실천의 의지가 없이도 사회적 도덕 문 제를 해결할 수 있을까?

\section{나. 3 학년}

3학년 도덕 교과서에서도 사회 생활 영역 III. 민주 사회와 도덕 문제 - 2. 민주적 태도와 생활 양식에
법교육 내용이 있다. 여기서는 2 학년 교과서에 비해 더욱 직접적으로 책임과 준법 정신을 다루고 있는데, 우리 사회에서 법이 잘 지켜지지 않는 이유를 여러 가지 역사적 실례를 들어가며 설명하였다. 정실주의와 집단 이기주의, 편법주의, 일제 시대로부터의 비정통 적인 정치 체제 등이 국민들의 법의식을 낮게 한 원 인이라는 것이다. 그리고 이러한 사회 풍토를 불식시 켜 법을 지키는 사람이 높이 평가받는 사회를 만들어 야 한다고 다음과 같이 주장한다.

복잡한 생산 공정에서 극히 작은 부분 하나라 도 제대에 제 기능을 다하지 못하면 전체 생산 공정이 제대로 작동될 수 없는 것처럼, 만일 사 회 안에 사는 시민 한 사람 한 사람이 약속된 법이나 공중 도덕을 지키지 않는다면, 그 국가 사회는 서로 믿지 못하고 안정되지 못해 발전하 기는커녕 무너질 수도 있다. 이것은, 아무리 튼 튼한 둑이라도 구멍 하나로 무너지게 된는 것과 같은 이치이다. 모든 것이 복잡하게 얽힌 현대 산업 사회에서 그 사회가 정한 공동 약속으로서 의 법 질서를 어긴다는 것은, 아무리 사소한 일 일지라도 개인과 사회 전체의 안녕과 번영에 피 해를 가져다 준다.

우리 사회에는, 법을 잘 지키고 원칙을 중요시 한는 사람을 고지식하고 우둔한 사람으로 여기며, 법은 덮어 두고 인정만으로 문제를 해결하고 그 것에 따라서 행동하는 사람이 더 인간미가 있고 여유 있다고 생각하는 사람까지 생기게 되었다.

이와 같은 사람들의 낮은 법 의식은, 우리의 오랜 가족 중심주의적 경향과 일제 치하에서 통 치 기구를 부정시하고 저항해 왔던 식민지 경험, 그리고 산업화에 따른 능률 위주의 사회적 픙토 등에 큰 영향을 받아 생겨나게 되었다.

좀더 상세히 말하면, 먼저, 우리 국민들은 공 동체 전체를 위한 사회적 준법보다는 대체로 가 족 중심의 인간 관계를 중시해 왔다. 아무리 나 쁜 짓을 하더라고 가족과 문중 사이에서는 이를 쉬쉬 해 가면서 감추려고 하는 것을 당연하게 생각하는 경향이 있어 왔다.

다음으로, 일제 식민지 통치하에서 법은 우리 
민족을 억압하는 수단이었기 때문에 법을 어기 거나 식민지 권력에 저항하는 것은 애국적 행위 로 정당화되었다. 이러한 영향으로 광복 후에도 법이나 정부의 정책을 존중하지 않는 폐습이 남 게 되었다.

또, 1960년대 이후 고도의 경제 성장 과정에서 결과에만 관심을 쏟은 나머지, 그 절차나 과정은 소홀히 여기는 경향이 생겼다. 즉 편법주의, 요령 주의가 발생하여, 무슨 일이든지 목적을 위해서는 수단과 방법을 가리지 않는 경향을 띠게 되었다. 그 결과, 법을 지키려는 정신은 희바 긱해지고, 법 대로 살면 오히려 손해를 본다는 의식을 가지게 된 것이다. 이러한 사회 풍토에서 모든 사람에게 높은 준법 정신을 기대하기란 어여운 일이다.

우리 모두가 바라는 정의로운 민주 사회는 정 직하고 성실하며 법대로 살아가는 사람이 결국 인정받는 사회이다. 즉, 법을 위반하거나 교묘한 수단으로 탈법을 자행하고서는 도저히 우리 사 회에서 살아갈 수 없으며, 법대로 사는 사람만이 높이 평가받는 사회적 풍토를 만들도록 우리 모 두가 노력해야만 한다.

\section{4. 고등학교 윤리 교과서의 법교육 내용}

고등학교 윤리 교과서에는 법교육 내용이 포함되어 있지 않고, II. 사회와 윤리 단원 중에 시민 생활 윤 리, 생명 존중 윤리, 환경과 윤리, 과학과 윤리 등의 소단원에서 간접적으로 법의식이 다루어지고 있다.

\section{IV. 도덕과 교과서 법교육 내용의 문제점과 개선 방안}

앞에서 초. 중 고등학교 도덕 윤리과 교과서의 법교육 및 관련 내용을 시례를 들어 분석하였다. 분석 결과 대체로 법실증주의를 중심으로 준법 정신을 강 조하면서도 실정법을 초월한 자연법 사상도 깃들어있 음을 알 수 있다. 이 점은 도덕과 교과서가 사회과 교 과서와 차별되는 점으로서 바람직한 면이다. 사회과 교 육에서 다루는 법교육은 주로 법의 개념, 법의 과정,
법의 체계, 현실 적용, 헌법 민법 국제법 등 구체적 인 실정법의 종류와 내용이 그 중심을 이룬다. 이에 비 해 도덕과에서의 법교육은 법을 지켜야 하는 이유, 법 의 근본 정신으로서의 인간 존중, 나아가 실정법을 초 월한 개인의 양심과 공동체 의식, 연대감을 강조하고 있음을 알 수 있다. 다음의 예가 이를 잘 보여준다.

사회적 도덕 문제는 인간의 사회 생활 과정에서 일 어나는 문제로서, 사회 생활의 여러 분야에서 나타나 며, 그 해결도 경우에 따라 다르다. 사회적 도덕 문제 의 해결은 사회 구성원 개인의 양심이나 도덕적 판단 보다는 사회적 제도나 규칙을 통하여 해결해야 하는 경우가 많다.

그러나 제도와 규칙만으로 사회적 도덕 문제를 모 두 해결할 수 있을까? 사회 구성원들의 양심에 의한 판단이나 도덕 실천의 의지가 없이도 사회적 도덕 문 제를 해결할 수 있을까?

이와 같은 장점과 아울러 도덕과 교과서에 수록된 법교육 내용 및 그 제시 방식에서 몇 가지 문제점을 발견할 수 있다.

첫째, 법교육 및 관련 내용을 완제품 형식의 지식으 로 제시하고 있다는 점이다. 김재복 등의 연구에 의하 면, 우리 나라의 전통적인 교과서의 구성 방식은 대부 분 논리적인 순서에 입각하여 치밀하게 조직되어, 학습 자가 파고 들어갈 틈이 없는 '객관적인 진리를 담아놓 은 그릇으로 되어 있다(김재복 외, 1997). 이러한 지적 은 도덕(윤리)과 교과서의 법교육 내용에도 대체로 해 당되며, 학교급과 학년이 올라갈수록 이러한 형태가 더 욱 심각해진다. 즉 교과서에 제시된 내용의 서술 형식 이 규범적이고 당위적이며 단정적으로 되어 있어 학생 들의 창의적. 개방적 사고가 제한될 우려가 있다. 예컨 대 “ 해야 한다."는 진술이 많으며, 질문을 제시하는 경우에도 “ 할까?, 말까?” 등의 진술이 대부분이다. 또 한 각 제재의 도입글과 제시된 문제 시태도 자세히 들 여다보면 가치 판단이 이미 개입되어 있는 경우가 많 다. 초등학교 교과서에는 학생들의 일상 생활과 관련된 문제 시태가 제시되어 있으나 규범을 직접 설명하고 있 어, 그 이상의 사고를 진전시키지 못할 수 있다. 둘째, 학교급별 내용의 연계가 약하다. 앞에서 제시한 바와 같이 고등학교 윤리 교과서에는 직접적인 법교육 내용 이 없다. 이 사실은 초등학교외중학교에서 배워 습득한 
법의식과 태도가 지속적으로 내면화되기 어려움을 말해 준다. 특히 고등학생은 곧 직장 및 사회 생활을 할 준 비 단계이므로 법교육이 필요하다. 또한 학교급과 핵년 별 위계의 문제도 지적할 수 있다. 중학교 3핵년 교과 서에서는 법대로 사는 사람을 높이 평가하고 있는데 비 해 초등학교 5 학년에서는 법없이 살 사람을 더 높은 수 준으로 묘사하고 있다. 그러면 이러한 문제점을 개선 하기 위해서는 어떤 내용을 어떻게 구성하는 것이 바람 직한가? 위의 문제점과 관련지어 첫째, 관련된 지식이 나 사실을 일러주는 방식을 지양하고 학생들의 일상 생 활과 밀접한 시례나 우리 사회의 쟁점 중심으로 내용을 구성해야 할 것이다. 특히 중학교 이상의 교과서에서는 현재 우리 사회에서 문제가 되고 있는 쟁점을 학생들이 토론이나 탐구를 통해 해결 방법을 찾아내는 방식으로 내용이 제시되는 것이 바람직하다. 법은 우리 모두에게 영향을 준다. 법은 의식있는 학생이라면 간과해서는
안될 중요한 우리 사회의 문제나 논쟁거리 또는 본질 적 가치와 직접적으로 관련되어 있다. 또한 법교육은 학생들에게 우리 사회에 발생하고 있는 문제에 대한 절대적인 정답을 주지도 않을 것이고 또 그렇게 할 수 도 없다. 그 대신에 진정한 법교육의 가치는 학생들의 신중한 탐구와 합리적인 사고력과 법에 대한 올바른 태도를 형성하는 데에 있다.

둘째, 고등학교 교육과정과 교과서에서도 법교육 내 용이 포함되어야 하며, 학교급, 학년급 내용을 연계성 있게 구성해야 할 것이다. 즉 초등학교 1핵년부터 고 등학교까지의 연계된 법교육을 위한 교육과정을 재구 성하여 학년 수준에 맞게, 그리고 지속적으로 연계된 교육을 하도록 해야 할 것이다. 예를 들어 초등학교 저학년 수준에서는 기본 규칙 지키기, 고학년에서는 공중 도덕 지키기, 중학교에서는 준법 정신, 고등학교 에서는 법의 이념과 연원 등을 지도할 수 있도록 한다.

\section{참 고 문 헌}

강윤정, 「법의식 발달에 관한 연구」, 서울대학교 석 사학위 논문, 1991.

김영진, '도덕과 예절에 관한 한 연구 - 한국의 도덕 과 예절을 중심으로-」, 인하대학교 인문과학연구 소, 「인문연구 제26집」, 1997.

김일수, 「법 - 인간 - 인권」, 서울: 박영사, 1990.

김재복 김왕근 양미경, 교과서 체제 개선 연구 -제 7 차 교육과정에 따른 교과서 내용 구성 방식을 중 심으로-, 한국교육과정연구회, 1997.

문용린, 「청소년의 도덕성, 법의식 발달, 비행 경향성 및 법교육 실태에 관한 연구」, 서울: 한국형사정 책연구원, 1994.

윤현진, 「한국 교육 이념의 법철학적 해석」, 한국정 신문화연구원 박사학위 논문, 1995.

이수성, "한국 청소년의 법의식에 관한 연구", 서울 대학교, 「법학, 제25권 제3호, 1984.

임희섭, "한국인의 법의식에 관한 사회햑적 연구, 서 울대학교, 「법학」 제 15 권 제 1 호, 1974.

정해창, "법과 도덕의 관계에 대하여", 법 및 사회철 학 한국학회 편, ${ }^{\prime}$ 법철학과 사회철학」, 창간호, 1991.

조영달, 박성혁, "한국 학생의 법태도 발달과 법교육 개선에 관한 연구, 민주문화아카데미, 「민주문화
논총」, 1992, 9.

최종고, 「법과 종교와 인간, 서울: 삼영사, 1992.

—, '법과 윤리」, 서울: 경세원, 1992.

- , '한국인의 법감정」, Fides, 서울대학교 법과대 학, 제 27 집 제 1 호, 1970.

한상범, '한국인의 법의식에 관한 법사회학적 연구」, 동국대학교 박사학위논문, 1975.

황경식, 「개방 사회의 사회 윤리」, 서울: 철학과 현실 사, 1996.

Beyleveld, D. \& Brownsword, R., Law as a Moral Judgement, London: Sweet \& Max-well, 1986.

Detmold, M, J, The Unity $f$ Law and Morality, London: Routledge \& Kegan Paul, 1984.

Friedman, Lowrence M., Law and Society: an Introduction, 박남규 역, 「법과 사회」, 서울; 법문 사, 1984.

Hacker, P.M.S. \& Raz, J., Law, Morality and Society, Oxford: Clarendon Press, 1979.

Lyons, David, Ethics and the Rule of Law, Cambridge: Cambridge Univ. Press, 1984.

Warnock, G. J., The Object of Morality, London: Methuen, 1971. 